\title{
Assessment of concentration and penetration depth of cisplatin in human lung tissue after decortication and hyperthermic exposure
}

\author{
Christopher Larisch ${ }^{1}$, Till Markowiak ${ }^{1}$, Elena Loch $^{1}$, Christian Großer ${ }^{2}$, Patrick J. Bednarski ${ }^{3}$, \\ Karolina Mueller ${ }^{4}$, Hans-Stefan Hofmann ${ }^{1,2}$, Michael Ried ${ }^{1}$ \\ ${ }^{1}$ Department for Thoracic Surgery, University Medical Center Regensburg, Franz-Josef-Strauss-Allee 11, 93053 Regensburg, Germany; \\ ${ }^{2}$ Department for Thoracic Surgery, Hospital Barmherzige Brüder Regensburg, Prüfeninger Str. 86, 93049 Regensburg, Germany; ${ }^{3}$ Institute of \\ Pharmacy, University of Greifswald, Friedrich-Ludwig-Jahnstrasse 17, 17489 Greifswald, Germany; ${ }^{4}$ Center for Clinical Studies, University Medical \\ Center Regensburg, Franz-Josef-Strauss-Allee 11, 93053 Regensburg, Germany \\ Contributions: (I) Conception and design: M Ried, C Larisch; (II) Administrative support: M Ried, T Markowiak, C Larisch; (III) Provision of study \\ materials or patients: M Ried, HS Hofmann, C Großer, E Loch, C Larisch; (IV) Collection and assembly of data: C Larisch, P Bednarski; (V) Data \\ analysis and interpretation: C Larisch, K Müller, P Bednarski; (VI) Manuscript writing: All authors; (VII) Final approval of manuscript: All authors. \\ Correspondence to: Michael Ried, MD. Department of Thoracic Surgery, University Medical Center Regensburg, Franz-Josef-Strauss-Allee 11, 93053 \\ Regensburg, Germany. Email: michael.ried@ukr.de.
}

Background: Hyperthermic perfusion of the pleural cavity with cisplatin after pleurectomy/decortication is an additional therapeutic option to reduce local relapse of malignant pleural tumours. Although there are data on the clinical effect, only little is known about the local impact on human lung tissue by cisplatin. The objective of this experimental study is to evaluate both the concentration and the penetration depth of cisplatin in human lung tissue after normothermic and hyperthermic exposure under ex-vivo-in-vitro conditions.

Methods: This study was approved by the local ethics committee. In total, 46 patients underwent elective lobectomy and wedge resections were taken from the resected lobes. A decortication of the visceral pleura was performed under ex-vivo conditions, and the tissue samples were incubated with cisplatin $(\mathrm{c}=0.05 \mathrm{mg} / \mathrm{mL})$ at 37,42 or $45^{\circ} \mathrm{C}$ for 60 minutes. Then the mass concentration of platinum was measured with flameless atomic absorption spectroscopy and then converted into cisplatin concentration. In addition, the current data were compared with previous data of our working group $\left(42^{\circ} \mathrm{C}\right.$, without decortication).

Results: The overall maximum penetration depth was $7.5 \mathrm{~mm}$ due to limitations of our methods. The functional maximum penetration depth did not vary with temperature $(\mathrm{P}=0.243)$ but by decortication $(\mathrm{P}<0.001)$. The cisplatin concentration decreased with increasing penetration depth $(\mathrm{P}<0.001)$. An increase of temperature showed no effect on the cisplatin concentration in decorticated tissue samples $(\mathrm{P}=0.985)$. However, decortication at $42{ }^{\circ} \mathrm{C}$ significantly increased the cisplatin concentration in comparison to not decorticated tissue samples $(\mathrm{P}=0.005)$.

Conclusions: Decortication of the visceral pleura increases the cisplatin concentration in the lung tissue. Therefore, it possibly reduces the likelihood of a local relapse. An increase of temperature did not show any effect.

Keywords: Hyperthermic perfusion; chemotherapy perfusion; penetration depth; cisplatin

Submitted Sep 10, 2020. Accepted for publication Mar 08, 2021.

doi: 10.21037/atm-20-6307

View this article at: http://dx.doi.org/10.21037/atm-20-6307 


\section{Introduction}

One of the biggest challenges in thoracic oncology is the treatment of malignant pleural mesothelioma (MPM), a rare tumor entity mainly caused by exposition to asbestos with a latency period of 30 years (1) and reaching its peak of incidence at about 2020 (2). Conventional chemotherapy alone only shows a median survival of less than one year (3). Due to its diffuse growth, only a macroscopic resection is achievable, preferring lung tissue conserving techniques as pleurectomy/decortication (P/D) or extended (e)P/D (4,5). In consequence, unclear resection margins as well as metastatic extrapleural nodes show a worse outcome (6). As a result, concepts of additional intracavitary chemotherapy were developed to improve local tumor control within a multimodal treatment regime. Today the additional HITOC (hyperthermic intrathoracic chemotherapy) is the most commonly used method, with reliable data on pharmacokinetics $(7,8)$, clinical safety (9-11) and potential benefit in survival (12-14).

However, there is only little known about the local effects of the administered drugs (mostly a combination with cisplatin) on the lung tissue, including maximum depth of penetration and whether therapeutically effective doses are applied. A previous ex-vivo-study of our working group showed that the penetration depth of cisplatin in not decorticated human lung tissue was approximately $3-$ $4 \mathrm{~mm}$ at $42{ }^{\circ} \mathrm{C}(15)$. Another ex-vivo-study emphasizes the importance of dose, combination of cytostatic drugs and temperature on the survival of MPM-cell lines, whereas the time of treatment was not decisive (16). Further data are inconsistent in whether MPM-cells are sensitive or rather resistant to commonly applied concentrations of cisplatin $(17,18)$.

The objective of this experimental study was to evaluate both the concentration and the penetration depth of cisplatin in human lung tissue after decortication and hyperthermic exposure under ex-vivo-in-vitro conditions.

We present the following article in accordance with the MDAR reporting checklist (available at http://dx.doi. org/10.21037/atm-20-6307).

\section{Methods}

\section{Patients and study design}

This experimental study was approved by the local Ethical Committee of the University of Regensburg (reference number: 19-1379-101). The trial was conducted in accordance with the Declaration of Helsinki (as revised in 2013). All patients signed an informed consent before participating in the study. Patients were included between March 2019 and March 2020. Criteria for inclusion were an age older than 18 years, elective anatomical lung resection (lobectomy) and no obtained neoadjuvant therapy like previous radiochemotherapy. Neither randomisation nor blinding was conducted. Participating hospitals were the departments of thoracic surgery of the University Medical Center Regensburg and of the Hospital Barmherzige Brüder Regensburg. The experimental investigations took place in the laboratory of the Department of Thoracic Surgery at the University Medical Center Regensburg. The analyses of the specimens were performed in the Institute of Pharmacy of the University of Greifswald. In total, 55 patients underwent elective lobectomy due to tumor diseases and wedge resections with stapler devices were taken from the resected lobes under ex-vivo conditions. Eight tissue samples were rejected due to small diameter and one sample was used as blank sample, resulting in 46 included tissue samples.

\section{Experimental setting and pharmacokinetic analysis}

The tissue samples were transported into the laboratory without embedding in any fluid. A decortication of the visceral pleura was performed and the tissue samples (about $\left.3-10 \mathrm{~cm}^{3}\right)$ were incubated with cisplatin $(\mathrm{c}=0.05 \mathrm{mg} / \mathrm{mL})$ at 37,42 or $45^{\circ} \mathrm{C}$ for 60 minutes. The tissue samples were frozen in liquid nitrogen and subsequent slices of $50 \mu \mathrm{m}$ were prepared with a cryomicrotome (Leica CM1900). In each case, ten slices were put together in a $1.5 \mathrm{~mL}$ Eppendorf cup and incubated in a $0.9 \% \mathrm{NaCl}$ and $65 \%$ nitric acid solution (each $200 \mu \mathrm{L}$ per $100 \mathrm{mg}$ wet weight tissue) followed by a homogenisation (MP Biomedicals FastPrep-24) for one minute. We incubated the cups in a water bath at $80^{\circ} \mathrm{C}$ for 24 hours or until there was a clear solution. $30 \mu \mathrm{L}$ of the content from each cup were diluted with $970 \mu 1$ of water (dilution of 1:33). Then the mass concentration of platinum was measured with graphite furnace atomic absorption spectroscopy (AAS) at the University of Greifswald. Every sample was analysed in triplicate with a relative standard deviation of $5 \%$ or less. For each measurement series, a calibration with eight standards between 14.5 and $162 \mu \mathrm{g} / \mathrm{L}$ of platinum was performed by using a quadradic function; correlation coefficients (r) for the calibration curves were $>0.997$. Afterwards, the penetration of cisplatin was related to 


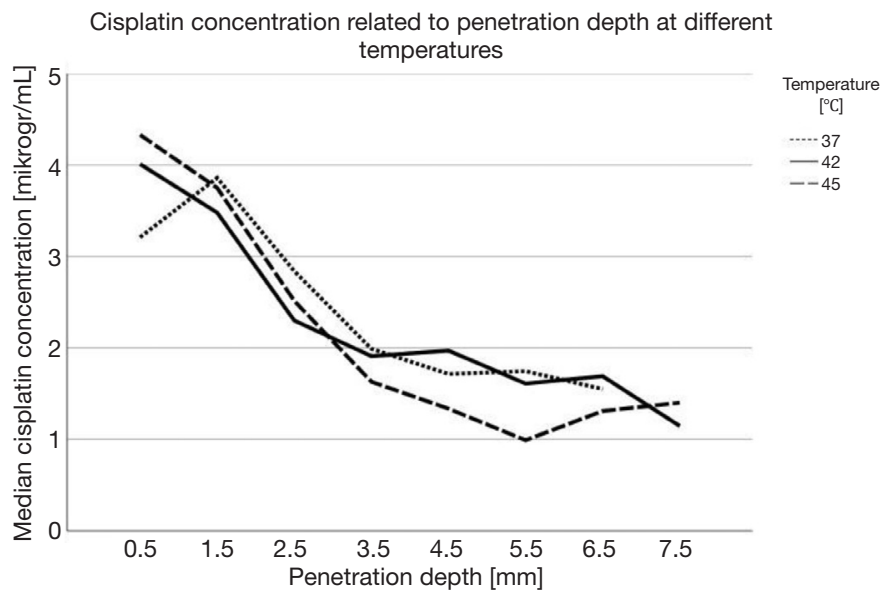

Figure 1 In decorticated tissue the median concentration of cisplatin decreased with increasing depth of penetration without significant difference at various temperatures.

the different platinum concentrations per tissue depth multiplied by the dilution factor. In addition, the current data were compared with previous data of our group $\left(42^{\circ} \mathrm{C}\right.$, without decortication). Due to the principle of graphite furnace AAS, we detected platinum instead of cisplatin itself. Thus, for better comparability with the common literature, the measured platinum concentrations were converted into cisplatin concentrations by using the following equation: $n_{\text {platinum }}=n_{\text {cisplatin }} ; m_{\text {cipplatin }}=\left(M_{\text {cisplatin }} / M_{\text {platimum }}\right) \times m_{\text {platinum }}$, whereby $n$ is the concentration of the respective species in $\mu \mathrm{g} / \mathrm{mL}$ and $M$ is the mole mass of the respective species. Provided that platinum is not or only in negligible quantity in the human body, we assume the measured platinum dose is equal or at least near to the exposed cisplatin dose.

\section{Statistical analysis}

Data collection and statistical analysis was performed by using IBM SPSS Statistics 25. The samples were characterized per lab parameters [absolute frequency (n), median (med), quartile (Q1/Q3), range].

Differences in functional maximum penetration depth (defined as a depth with a cisplatin concentration higher than $1 \mu \mathrm{g} / \mathrm{mL}$ ) between temperatures $\left(37,42\right.$ and $\left.45^{\circ} \mathrm{C}\right)$ were assessed by Kruskal-Wallis-H-test and between decorticated versus non-decorticated tissue by MannWhitney-U-test. Due to the small sample size, nonparametric methods were used.

Based on repeated measures, mixed linear models (MLM) were used to assess the correlation of cisplatin concentration and penetration depth as well as the differences of cisplatin concentration in decorticated tissue between different temperatures $\left(37,42,45^{\circ} \mathrm{C}\right)$ and between decorticated and non-decorticated tissue at $42^{\circ} \mathrm{C}$. Parameter estimation of MLMs was based on maximum likelihood method and autoregressive repeated covariance type was used as the correlation of cisplatin concentration between the measurements (penetration depth) gets less as penetration depth gets further apart. Estimates and $95 \%$ confidence interval (CI) were reported.

The two-sided level of significance was set at $\mathrm{P} \leq 0.05$. The analysis was only explorative and thus no adjustment for multiple testing was conducted.

\section{Results}

The tissue samples $(n=46)$ included seven decorticated samples at $37^{\circ} \mathrm{C}, 13$ decorticated samples at $42{ }^{\circ} \mathrm{C}, 14$ nondecorticated samples at $42{ }^{\circ} \mathrm{C}$ and 12 decorticated samples at $45^{\circ} \mathrm{C}$. General trends of cisplatin concentration are shown in Figures 1 and 2. Further information about penetration depth and concentration of cisplatin are presented in Table 1.

The overall maximum penetration depth of cisplatin was $7.5 \mathrm{~mm}$ (limited by our method), with a median of $4.5 \mathrm{~mm}$ $(\mathrm{n}=46, \mathrm{Q} 1 / \mathrm{Q} 3=3.5 / 5.8$; range, 2.5-7.5). The functional maximum penetration depth (defined as a depth with a cisplatin concentration higher than $1 \mu \mathrm{g} / \mathrm{mL}$ ) did not significantly differ in decorticated tissue between various temperatures $(\mathrm{P}=0.243$; Figure 3$)$ but between decorticated and non-decorticated tissue at $42{ }^{\circ} \mathrm{C}(\mathrm{P}<0.001$; Figure 4$)$. 


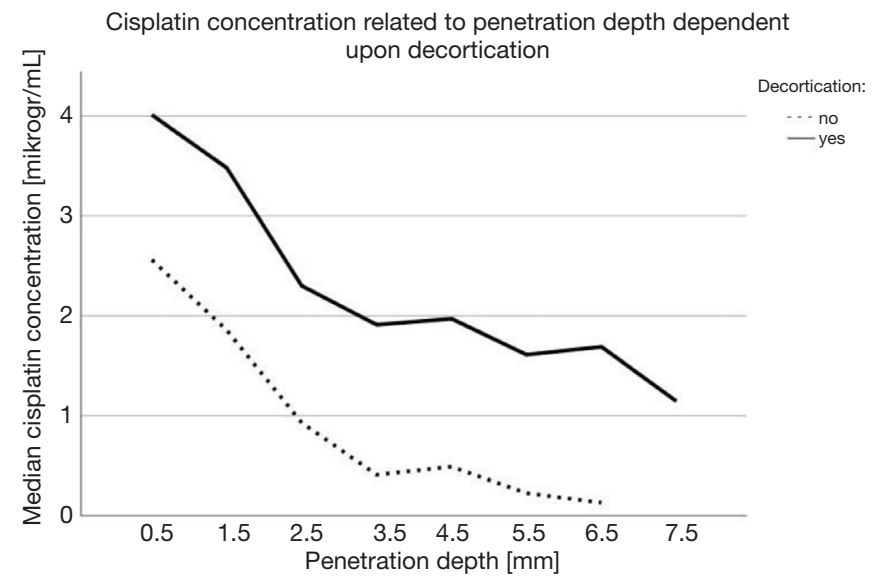

Figure 2 The median concentration of cisplatin $(\mu \mathrm{g} / \mathrm{mL})$ decreased with increasing depth of penetration at $42{ }^{\circ} \mathrm{C}$ with a significant difference upon the tissue was decorticated or not.

Table 1 Descriptive statistics: penetration depth and cisplatin concentration related to temperature and decortication

\begin{tabular}{|c|c|c|c|c|c|c|c|c|c|c|c|c|c|c|c|c|}
\hline & \multicolumn{4}{|c|}{$37^{\circ} \mathrm{C}$ decorticated } & \multicolumn{4}{|c|}{$42{ }^{\circ} \mathrm{C}$ not decorticated } & \multicolumn{4}{|c|}{$42{ }^{\circ} \mathrm{C}$ decorticated } & \multicolumn{4}{|c|}{$45^{\circ} \mathrm{C}$ decorticated } \\
\hline MPD & 7 & 5.50 & 3.50 & 6.50 & 14 & 4.50 & 3.50 & 4.50 & 13 & 4.50 & 4.50 & 5.50 & 12 & 6.00 & 4.50 & 7.25 \\
\hline functional MPD & 7 & 3.50 & 2.50 & 5.50 & 14 & 1.50 & 1.25 & 2.50 & 13 & 4.50 & 3.50 & 5.50 & 12 & 6.00 & 3.75 & 6.50 \\
\hline $\mathrm{CC}$ at $0.5 \mathrm{~mm}$ & 6 & 3.21 & 1.81 & 4.68 & 12 & 2.56 & 1.65 & 3.17 & 13 & 4.01 & 2.75 & 5.68 & 12 & 4.33 & 2.62 & 5.71 \\
\hline $\mathrm{CC}$ at $2.5 \mathrm{~mm}$ & 7 & 2.84 & 2.15 & 3.52 & 13 & 0.93 & 0.44 & 1.07 & 12 & 2.30 & 1.43 & 3.30 & 12 & 2.52 & 1.84 & 3.98 \\
\hline $\mathrm{CC}$ at $3.5 \mathrm{~mm}$ & 6 & 1.99 & 1.41 & 2.79 & 13 & 0.41 & 0.13 & 0.72 & 13 & 1.91 & 1.03 & 2.64 & 12 & 1.63 & 1.30 & 2.56 \\
\hline $\mathrm{CC}$ at $4.5 \mathrm{~mm}$ & 4 & 1.71 & 0.78 & 2.20 & 9 & 0.49 & 0.16 & 0.77 & 11 & 1.97 & .99 & 2.58 & 10 & 1.34 & 0.91 & 1.94 \\
\hline $\mathrm{CC}$ at $5.5 \mathrm{~mm}$ & 4 & 1.75 & 1.61 & 2.37 & 2 & 0.23 & 0.19 & & 5 & 1.61 & 1.20 & 2.36 & 8 & 0.99 & 0.69 & 1.16 \\
\hline
\end{tabular}

$\mathrm{CC}$, concentration of cisplatin $[\mu \mathrm{g} / \mathrm{mL}]$; MPD, median maximum penetration depth [mm]; functional MPD, median maximum penetration depth [mm] with a cisplatin concentration higher than $1 \mu \mathrm{g} / \mathrm{mL}$; Q1/Q3: first/third quartile.

Two MLMs were computed: MLM 1 for decorticated tissue to compare cisplatin concentration between temperatures and MLM 2 to compare cisplatin concentration between decorticated and non-decorticated tissue at $42{ }^{\circ} \mathrm{C}$. Results are presented in Table 2. In both cases, the cisplatin concentration decreased significantly with increasing penetration depth $(\mathrm{P}<0.001)$. The cisplatin concentration decreased approximately $0.5 \mu \mathrm{g} / \mathrm{mL}$ per $1 \mathrm{~mm}$ of penetration depth. The mean cisplatin concentration did not differ between various temperatures in decorticated tissue $(\mathrm{P}=0.985)$. However, the mean cisplatin concentration was significantly higher in decorticated compared to not decorticated tissue at $42{ }^{\circ} \mathrm{C}$ (mean difference $=1.34 \mu \mathrm{g} / \mathrm{mL}$; 95\% CI: $-2.25,-0.44 ; \mathrm{P}=0.005)$.

\section{Discussion}

A big challenge in the surgical therapy of MPM are the residual tumor cells on the lung surface even after complete decortication. The objective of the additional HITOC after surgical cytoreduction with macroscopic complete tumor resection is the eradication of those remaining tumor cells 


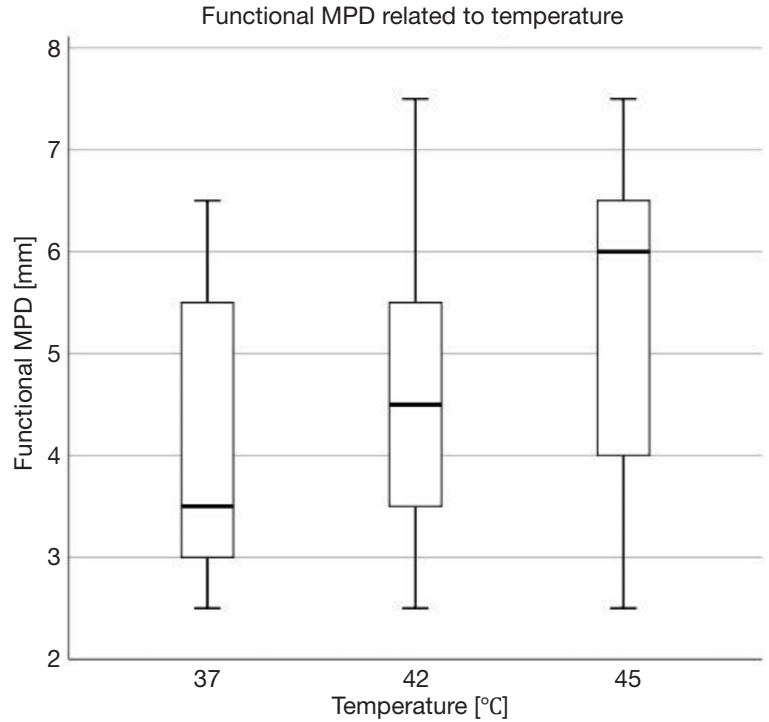

Figure 3 Temperature $\left({ }^{\circ} \mathrm{C}\right)$ does not significantly vary functional maximum penetration depth $[\mathrm{mm}]$ in decorticated tissue; functional MPD: functional maximum penetration depth.

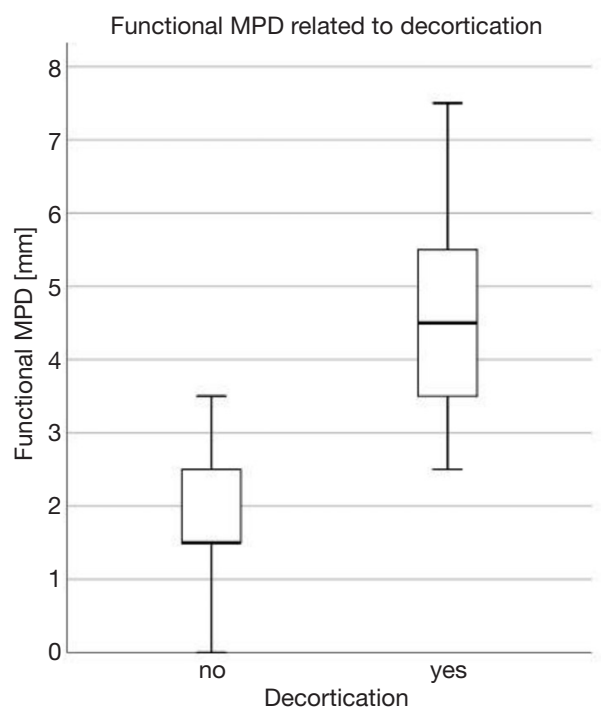

Figure 4 Decortication does significantly vary functional maximum penetration depth $[\mathrm{mm}]$ at $42{ }^{\circ} \mathrm{C}$, functional MPD, functional maximum penetration depth.

in order to improve local tumor control and by that the patients' survival. However, the local effects of the HITOC including chemotherapeutic agents (e.g., cisplatin) on the lung tissue remain unclear. A previous ex-vivo-study of our group estimated the penetration depth of cisplatin in not decorticated lung tissue to be $3-4 \mathrm{~mm}$ at $42{ }^{\circ} \mathrm{C}(15)$.
Table 2 MLM of cisplatin concentration related to temperature and decortication

\begin{tabular}{lccccc}
\hline & $\mathrm{n}$ & Estimate $^{\ddagger}$ & $95 \% \mathrm{Cl}$ & $\mathrm{P}$ \\
\hline MLM 1 & & & & & \\
Penetration depth & 182 & -0.46 & -0.57 & -0.35 & $<0.001$ \\
Temperature $\left({ }^{\circ} \mathrm{C}\right)$ & & & & & \\
37 & 36 & 2.62 & 1.96 & 3.29 & 0.985 \\
42 & 71 & 2.70 & 2.22 & 3.17 & \\
45 & 75 & 2.68 & 2.20 & 3.16 & \\
MLM 2 & & & & & \\
Penetration depth & 135 & -0.54 & -0.69 & -0.40 & $<0.001$ \\
Decortication & & & & & \\
No & 64 & 1.54 & 0.91 & 2.18 & 0.005 \\
Yes & 71 & 2.89 & 2.25 & 3.53 & \\
\hline
\end{tabular}

MLM 1: The mean cisplatin concentration in decorticated tissue decreased with increasing penetration depth (on average $0.46 \mu \mathrm{g} / \mathrm{mL}$ per $1 \mathrm{~mm} ; \mathrm{P}<0.001$ ) but did not differ between temperatures $(P=0.985)$. MLM 2: The mean cisplatin concentration decreased with increasing penetration depth at $42{ }^{\circ} \mathrm{C}$ (on average $0.54 \mu \mathrm{g} / \mathrm{mL}$ per $1 \mathrm{~mm}$; $\mathrm{P}<0.001$ ) and was higher in decorticated tissue than in not decorticated tissue $(P=0.005)$. MLM, mixed linear model. ${ }^{\ddagger}$, estimate of cisplatin concentration.

Now, we have taken a step closer to in-vivo-conditions by both decorticating the visceral pleura and varying the temperature. Summarising, overall penetration depth was $7.5 \mathrm{~mm}$ due to our limited methods. The functional maximum penetration depth increased after decortication, but it does not differ at different temperatures. Second, cisplatin concentration decreased at about $0.5 \mu \mathrm{g} / \mathrm{mL}$ per $1 \mathrm{~mm}$ of penetration depth. Third, overall cisplatin concentration did not differ between various temperatures, but it was increased by decortication.

Ratto et al. collected lung tissue samples taken after P/D and intracavitary perfusion with cisplatin $\left(100 \mathrm{mg} / \mathrm{m}^{2}\right.$ BSA) for $60 \mathrm{~min}$ and found that the cisplatin concentration is enhanced by hyperthermia $\left(42\right.$ vs. $\left.37^{\circ} \mathrm{C}\right)(19)$. This is contrary to our results. Cameron and Hou investigated survival rates of MPM cell lines ex-vivo that were exposed to hyperthermia of $42^{\circ} \mathrm{C}$ and cisplatin doses of 1,2 and $4 \mu \mathrm{g} / \mathrm{mL}$ (16). Combining their data with our data on decorticated tissue samples at $42^{\circ} \mathrm{C}$, we assume survival rates of MPM cells of $15-25 \%$ at $0.5 \mathrm{~mm}$ and approximately 30 $50 \%$ at 3.5 to $4.5 \mathrm{~mm}$. In not-decorticated tissue samples at $42{ }^{\circ} \mathrm{C}$ the approximate survival rate would be more than 
$30-50 \%$ at $0.5 \mathrm{~mm}, 30-60 \%$ at $2.5 \mathrm{~mm}$ and even higher at a penetration depth greater than $3.5 \mathrm{~mm}$. This implicates that more tumor cells are killed at a greater depth after decortication. Another study could demonstrate, that in five out of six pleural fluid samples (could be considered as a penetration depth of zero) the cytology was negative for the presence of neoplastic cells after HITOC when compared with the sample of pleural fluid taken immediately after the chest was opened (20). Opitz et al. even evolved another form of intracavitary chemotherapy by using the combination of fibrin glue with cisplatin being sprayed onto the resected lung surface instead of fluid agents (21). This might have an additional effect on the risk of local relapse and survival due to a longer period of exposition to the cytostatic drugs and thus higher concentrations.

The applied cisplatin dose for HITOC used to be 100 $150 \mathrm{mg} / \mathrm{m}^{2}$ body surface area (BSA). With increasing clinical experience and optimizing our perioperative management $(7,9)$, we now administer a cisplatin dose of $175 \mathrm{mg} / \mathrm{m}^{2}$ BSA in all our HITOC procedures and without clinically relevant renal complications due to nephroprotection (11). As described in the literature, higher cisplatin concentrations are associated with prolonged survival rates in patients with MPM $(12,22)$. During HITOC the total amount of cisplatin of $300-350 \mathrm{mg} / \mathrm{m}^{2}$ (assuming a BSA of $1.7-2.0 \mathrm{~m}^{2}$ ) is diluted in approximately 4 liters of circulating volume. This corresponds to a cisplatin concentration in the perfusate of 0.075 and $0.0875 \mathrm{mg} / \mathrm{mL}$, respectively, which is a percentage increase of $50 \%$ and $75 \%$ compared to the described concentration of $0.05 \mathrm{mg} / \mathrm{mL}$ in this study. According to the study of Cameron and Hou, a higher cisplatin concentration is associated with a higher rate of tumor apoptosis (16). Thus, experimental investigations of our group are planned with higher concentrations of cisplatin as mentioned above.

There are some limitations on our results. First, this was an in-vitro-study within a highly controlled setting. Second, the penetration depth and concentration could be different in-vivo although we sought for fast processing of the tissue sample once they were resected. Third, we measured platinum instead of cisplatin due to our method and then converted the data.

In conclusion, our study emphasises the importance of an exact and complete $\mathrm{P} / \mathrm{D}$ in order to verify that the cisplatin reaches the tissue in sufficiently high dose. Therefore, it will possibly reduce the likelihood of a local relapse after a macroscopic complete tumor resection before HITOC. In the future, one of our next steps in experimental research is to steadily increase the applied cisplatin dose and to combine different cytotoxic agents in order to assess the local effects on lung tissue as well as tumor cell lines.

\section{Acknowledgments}

The authors especially appreciate the technical assistance of Karin Bielenberg, Department of Cardiothoracic Surgery, University Medical Center, Regensburg.

Funding: None.

\section{Footnote}

Provenance and Peer Review: This article was commissioned by the Guest Editor (Marcello Migliore) for the series "Hyperthermic Intraoperative Chemotherapy (HITHOC) in thoracic surgical oncology" published in Annals of Translational Medicine. The article has undergone external peer review.

Reporting Checklist: The authors have completed the MDAR reporting checklist. Available at http://dx.doi.org/10.21037/ atm-20-6307

Data Sharing Statement: Available at http://dx.doi. org/10.21037/atm-20-6307

Conflicts of Interest: All authors have completed the ICMJE uniform disclosure form (available at http://dx.doi. org/10.21037/atm-20-6307). The series "Hyperthermic Intraoperative Chemotherapy (HITHOC) in thoracic surgical oncology" was commissioned by the editorial office without any funding or sponsorship. The authors have no other conflicts of interest to declare.

Ethical Statement: The authors are accountable for all aspects of the work in ensuring that questions related to the accuracy or integrity of any part of the work are appropriately investigated and resolved. The study was conducted in accordance with the Declaration of Helsinki (as revised in 2013). This experimental study was approved by the local Ethical Committee of the University of Regensburg (reference number: 19-1379-101). All patients signed an informed consent before participating in the study. 
Open Access Statement: This is an Open Access article distributed in accordance with the Creative Commons Attribution-NonCommercial-NoDerivs 4.0 International License (CC BY-NC-ND 4.0), which permits the noncommercial replication and distribution of the article with the strict proviso that no changes or edits are made and the original work is properly cited (including links to both the formal publication through the relevant DOI and the license). See: https://creativecommons.org/licenses/by-nc-nd/4.0/.

\section{References}

1. Wagner JC, Sleggs CA, Marchand P. Diffuse pleural mesothelioma and asbestos exposure in the North Western Cape Province. Br J Ind Med 1960;17:260-71.

2. Peto J, Decarli A, La Vecchia C, et al. The European mesothelioma epidemic. Br J Cancer 1999;79:666-72.

3. Muers MF, Stephens RJ, Fisher P, et al. Active symptom control with or without chemotherapy in the treatment of patients with malignant pleural mesothelioma (MS01): a multicentre randomised trial. Lancet 2008;371:1685-94.

4. Rice D, Rusch V, Pass H, et al. Recommendations for uniform definitions of surgical techniques for malignant pleural mesothelioma: a consensus report of the international association for the study of lung cancer international staging committee and the international mesothelioma interest group. J Thorac Oncol 2011;6:1304-12.

5. Flores RM, Pass HI, Seshan VE, et al. Extrapleural pneumonectomy versus pleurectomy/decortication in the surgical management of malignant pleural mesothelioma: results in 663 patients. J Thorac Cardiovasc Surg 2008;135:620-6, 6.e1-3.

6. Sugarbaker DJ, Flores RM, Jaklitsch MT, et al. Resection margins, extrapleural nodal status, and cell type determine postoperative long-term survival in trimodality therapy of malignant pleural mesothelioma: results in 183 patients. J Thorac Cardiovasc Surg 1999;117:54-63; discussion 63-5.

7. Ried M, Potzger T, Braune N, et al. Local and systemic exposure of cisplatin during hyperthermic intrathoracic chemotherapy perfusion after pleurectomy and decortication for treatment of pleural malignancies. J Surg Oncol 2013;107:735-40.

8. van Ruth $\mathrm{S}$, van Tellingen $\mathrm{O}$, Korse CM, et al. Pharmacokinetics of doxorubicin and cisplatin used in intraoperative hyperthermic intrathoracic chemotherapy after cytoreductive surgery for malignant pleural mesothelioma and pleural thymoma. Anticancer Drugs
2003;14:57-65.

9. Ried M, Potzger T, Braune N, et al. Cytoreductive surgery and hyperthermic intrathoracic chemotherapy perfusion for malignant pleural tumours: perioperative management and clinical experience. Eur J Cardiothorac Surg 2013;43:801-7.

10. van Ruth S, Baas P, Haas RLM, et al. Cytoreductive surgery combined with intraoperative hyperthermic intrathoracic chemotherapy for stage I malignant pleural mesothelioma. Ann Surg Oncol 2003;10:176-82.

11. Markowiak T, Kerner N, Neu R, et al. Adequate nephroprotection reduces renal complications after hyperthermic intrathoracic chemotherapy. J Surg Oncol 2019;120:1220-6.

12. Sugarbaker DJ, Gill RR, Yeap BY, et al. Hyperthermic intraoperative pleural cisplatin chemotherapy extends interval to recurrence and survival among low-risk patients with malignant pleural mesothelioma undergoing surgical macroscopic complete resection. J Thorac Cardiovasc Surg 2013;145:955-63.

13. Tilleman TR, Richards WG, Zellos L, et al. Extrapleural pneumonectomy followed by intracavitary intraoperative hyperthermic cisplatin with pharmacologic cytoprotection for treatment of malignant pleural mesothelioma: a phase II prospective study. J Thorac Cardiovasc Surg 2009;138:405-11.

14. Zhao ZY, Zhao SS, Ren M, et al. Effect of hyperthermic intrathoracic chemotherapy on the malignant pleural mesothelioma: a systematic review and meta-analysis. Oncotarget 2017;8:100640-7.

15. Ried M, Lehle K, Neu R, et al. Assessment of cisplatin concentration and depth of penetration in human lung tissue after hyperthermic exposure. Eur J Cardiothorac Surg 2015;47:563-6.

16. Cameron RB, Hou D. Intraoperative hyperthermic chemotherapy perfusion for malignant pleural mesothelioma: an in vitro evaluation. J Thorac Cardiovasc Surg 2013;145:496-504.

17. Cregan IL, Dharmarajan AM, Fox SA. Mechanisms of cisplatin-induced cell death in malignant mesothelioma cells: role of inhibitor of apoptosis proteins (IAPs) and caspases. Int J Oncol 2013;42:444-52.

18. Matsuzaki $Y$, Tomita M, Shimizu T, et al. Induction of apoptosis by intrapleural perfusion hyperthermochemotherapy for malignant pleural mesothelioma. Ann Thorac Cardiovasc Surg 2008; 14:161-5.

19. Ratto GB, Civalleri D, Esposito M, et al. Pleural space perfusion with cisplatin in the multimodality treatment of 


\section{Page 8 of 8}

malignant mesothelioma: a feasibility and pharmacokinetic study. J Thorac Cardiovasc Surg 1999;117:759-65.

20. Migliore M, Calvo D, Criscione A, et al. Cytoreductive surgery and hyperthermic intrapleural chemotherapy for malignant pleural diseases: preliminary experience. Future Oncol 2015;11:47-52.

21. Opitz I, Lauk O, Meerang M, et al. Intracavitary cisplatinfibrin chemotherapy after surgery for malignant pleural

Cite this article as: Larisch C, Markowiak T, Loch E, Großer C, Bednarski PJ, Mueller K, Hofmann HS, Ried M. Assessment of concentration and penetration depth of cisplatin in human lung tissue after decortication and hyperthermic exposure. Ann Transl Med 2021;9(11):953. doi: 10.21037/atm20-6307

\section{Larisch et al. Cisplatin penetration in human lung tissue}

mesothelioma: A phase I trial. J Thorac Cardiovasc Surg. 2019. [Epub ahead of print]. doi: 10.1016/ j.jtcvs.2019.07.073.

22. Burt BM, Richards WG, Lee H-S, et al. A Phase I Trial of Surgical Resection and Intraoperative Hyperthermic Cisplatin and Gemcitabine for Pleural Mesothelioma. J Thorac Oncol 2018;13:1400-9. 